\title{
Anima/Animus and Wise Old Man in Six Characters in Search of an Author
}

\author{
Ali Jamalinesari \\ Young Researchers and Elite Club, Ilam Branch, Islamic Azad University, Ilam, Iran \\ E-mail: jamalinesari@yahoo.com
}

\author{
Doi:10.7575/aiac.alls.v.6n.3p.33 \\ URL: http://dx.doi.org/10.7575/aiac.alls.v.6n.3p.33
}

Received: 04/01/2014

Accepted: 13/03/2015

\begin{abstract}
The word 'archetype' is derived from the Greek words arche meaning 'first' and type meaning 'imprint' or 'pattern'. Actually, the archetypes are like deposits of experiences that have been frequently repeated in the history of human beings. They are present in all humans from birth. They can be represented in dreams, fantasies, or as a story, as a pattern or image such as mandala, or as an archetypal or mythical character. Jung believes that the archetypes are not memories of past experiences but are forms without content that represent a certain kind of perception and action. They offer a kind of preparation to produce similar mythical ideas again and again. Jung discovers that, since we have different cultures with different people, we have different kinds of archetypes - some known, many others yet to be discovered. In this regards, in the followings the archetypes Anima/Animus and Wise Old Man are discussed in Six Characters in Search of an Author to show how the question of reality, illusion and the oxymoron illusive reality as a major theme haunts Pirandello's play.
\end{abstract}

Keywords: Jung, Anima, Animus, Wise Old Man, Pirandello

\section{Introduction}

Carl Gustav Jung, born in July 1875- June 1961, is a Swiss psychoanalyst and the founder of the Jungian psychology. After a period of working with Freud, he separates his collaboration with him on the case that he sees Freud's view on psychoanalysis incomplete, and mostly psychiatric. After parting from Freud, Jung was able to pursue his unique approach to the unconscious contents of the mind, and particularly his interest in archetypal symbolism. Jung (1958) affirms that:

Mind is not born as a clean slate. Like the body, it has its pre-established individual definiteness; namely, forms of behavior. They become manifest in ever-recurring patterns of psychic functioning. (p.15)

In fact, Jung gets his inspiration from Freud, but adds his own experiences to his psychoanalysis too. Jung (1963) asserts that:

All my works, all my creative activity, has come from those initial fantasies and dreams which began in 1912, almost fifty years ago. Everything that I accomplished in later life was already contained in them, although at first only in the form of emotions and images. (p.192)

In his childhood, Jung was so lonely and was filled with dreams and fantasies. Later, he began to examine his dreams besides his patients' dreams and fantasies; the investigation of his inner reality leads the foundation for many of his psychological theories and concepts. Jung (1968) states that:

The general function of dreams is to try to restore our psychological balance by producing dream material that re-establishes, in a subtle way, the total psychic equilibrium. That is what I have called the complementary (or compensatory) role of dreams in our psychic make-up. (p.34)

Actually, dreams and fantasies are important for Jung. He discovers that most of his patients speak about different kinds of dreams and images, which he understands, are similar to each other, universal and can be found in most stories and myths. Therefore, he expresses that these dreams and images which are universal in his patients' dreams and myths are called 'archetypes'. In this respect, Guerin (1960) urges: 
The great artist is the man who possesses the "primordial vision", a special sensitivity to archetypal patterns and a gift for speaking in primordial images that enable him to transmit experiences of the "inner world" to the "outer world" through his art form .(p.178)

In the Jungian psychology the emphasis is on 'archetypes' which is the representation of human unconscious. Walker (2002) states that:

The Jungian literary criticism encourages a specific kind of symbolic reading of the texts [...]. Many works of literature, of course, have clear mythic subtexts and the interpretation of mythic patterns is a correspondingly central feature of the Jungian criticism. (pp. 146-147)

This conscious-unconscious interaction is important in the achievement of all creative activity, whether artistic or literary, which leads to the development of personality or individuation.

Deeper in the psyche, beneath the layers of the personal unconscious, are other layers that have been formed in every member of our species. All of these layers shape the collective unconscious and are the most prominent part for Jung. Jung (1969) affirms that:

Personal unconscious rests upon a deeper layer, which does not derive from personal experience and is not a personal acquisition but is inborn. I call this the collective unconscious. I have chosen the term "collective" because this part of the unconscious is not individual but universal; in contrast to the personal psyche, it has contents and modes of behavior that are more or less the same everywhere and in all individuals. It is, in other words, identical in all men and thus constitutes a common psychic substrate of a suprapersonal nature which is present in every one of us. (p.5)

In the dreams and fantasies of his patient's Jung finds ideas and images whose origins, he feels, could not be traced to the individual's personal experiences. Collective unconscious is not something to be acquired but to be inherited. The contents of the collective unconscious are "archetypes", which are common to all people. Jung (1969) states: "Whereas the personal unconscious consists for the most part of complexes the content of the collective unconscious is made up essentially of archetypes" (p. 31). The collective unconscious is different from personal unconscious. Unlike personal unconscious, which is made of contents that have been forgotten or repressed, collective unconscious does not develop from personal experiences; therefore, it is not a personal acquisition. Jung (1969) asserts that:

The concept of the archetype, which is an essential correlate of the idea of the collective unconscious, indicates the existence of definite forms in the psyche which seem to be present always and everywhere. (p. 31)

Jung discovers that, since we have different cultures with different people, we have different kinds of archetypes - some known, many others yet to be discovered. The most important archetypes are: Anima/Animus, Wise Old Man, Self.

\subsection{The Anima/Animus}

As it has been stated in Walker (2002), anima/animus, in fact, personifies the soul, or inner attitude. It has the characteristics of the opposite sex. In fact, they are other important archetypes in our unconscious. In Latin, they mean soul. The anima represents the feminine aspect in men, and comes from the individual man's experience with women as companion, and man's own minority of female genes.

Anima often appears in the dreams and remains unconscious. Moreover, it may be projected outwards onto different women such as mother, lover, and wife. This projection shows the man's passionate attraction or hatred toward women. Guerin (1960) states "in literature, Jung regards such figures as Helen of Troy, Dante's Beatrice, and Milton's Eve" (qtd. in Guerin et al., 1960, p.181). In fact, in literature, any woman who enters the story can be considered as an anima; therefore, anima can be both positive and negative. Walker (2002) states:

For a man who is unaware of his feminine side, the anima can easily play a negative role of archetypal temptress and deceiver- a Lorelei, a Belle Dame Sans Merci, a Calypso- subtly luring him into confusion and despair [...]. But she can also be a helpful figure, like Circe in the Odyssey; she can send a man on a journey into the depth of the unknown. Like Dante's Beatrice, she may become the inspiration for a great spiritual quest. (pp. 47-9)]

Animus, on the other hand, is the male personification in women. It may reflect in images such as man, father, husband and so on. In his positive aspect he is a woman's connection to the unconscious and self through creative activity. Like anima, animus can have both positive and negative aspects. An example for animus can be referred to Heathcliff in Emily Bronte's Wuthering Heights. Walker (2002) asserts that: 
In Emily Bronte's Wuthering Heights the foundling Heathcliff is a dark, demonic figure of extraordinary mythological resonance and he maybe said to represent the demon lover aspect of the animus [...]. Catherine has unconsciously projected her animus onto Heathcliff. She is unable to accept him as a husband because of her desire for the social status that marriage with Edgar Linton can give her. (p.56)

\subsection{The Wise Old Man}

Mana-personality or wise old man is another important archetype of meaning or spirit. As Antonio Moreno (1970) states: "In literature, this archetype appears when the hero feels trapped in situations in which he needs insight, understanding, good advice, determination, and planning"(p.58). It usually appears as grandfather, sage, magician, king, doctor, priest, or any other authority figure. It represents insight, wisdom, cleverness, and willingness to help. In this respect, animus can be regarded as a wise old man archetype.

\section{Discussion}

\subsection{Anima/Animus in the Father/Mother}

Based on Jung's theory (qtd. in Ruth Snowden, 2006), anima is a feminine aspect of the man, who helps the man to achieve his self. In this drama, the father's anima is the mother. As the father claims, "he marries her for her simplicity, that's what he loved in her" $(1979$, p.21). But later, he assumed a kind of relationship between his wife and his secretary. Actually, it was not right, since he confessed that "neither of them was capable even of thinking wrong, let alone doing it" (1979, p.22); therefore, one can consider that it is the father who is not able to understand his wife. He thinks that the 'simplicity' of his wife is the best thing for the marriage and will enable each one to understand each other just as he supposed "we think we understand each other: but we never do. Look! All my pity, all my compassion for this woman (pointing to Mother.) she sees as ferocious cruelty" (1979, p.21). However, in his case, he was not able to tolerate his wife and could not accept her as his wife. In this respect, he states that:

I couldn't bear the sight of this woman near me. (Pointing to the Mother) Not so much because of the annoyance she caused me, you see, or even the feeling of being stifled, being suffocated that I got from her, as for the sorrow, the painful sorrow that felt for her. (1979, p.23)

Moreover, the father speaks about "her deafness, her mental deafness, (he taps his forehead) affection for her children, oh yes, but deaf, mentally deaf, sir, to the point of desperation" (1979, p.21). Therefore, it seems that the father cannot make a relationship with the mother. Consequently, he decides to send the mother away with another man, in order to escape from his reality.

On the other hand, the mother's animus can be traced in the father, too. As the father declares, when he assumed a kind of relationship between the mother and his secretary, he sacked the secretary. But, then, he noticed the condition that the mother became depressed and "wandering about in the house on her own, forlorn, like a stray animal you take in out of pity" (1979, p.22). Additionally, the mother admits the occasion and says "it's quite true" (1979, p.22). Therefore, one can see the situation between them and will conclude that they were not able to understand and communicate together; when the mother returned to the father with her three children, the conversation which exchanged between them confirms this lack of understanding:

Father (Quickly, not giving her time to speak.): They were so miserable. They came back here, but I didn't know about it because of the Mother's stubbornness. (Pointing to the Mother) She can't really write you know; but she could have got her daughter to write, or the boy, or tell me that they needed help.

Mother: But tell me sir, how could I have known how he felt?

Father: And hasn't that always been your fault? You have never known anything about how I felt. (1979, pp.25-26)

Actually, each of them accuses the other side for not making a good life and not being able to understand the feelings and expectations of the other part.

\subsection{Wise Old Man in Six Characters in Search of an Author}

As Jung (1969) states, wise old man is a figure, who with his advices helps the hero or the characters in the situations in which they are trapped. In this drama, the concept of wise old man can be seen in two aspects: first, the author, and second, the producer. As one can see in the story, all the characters are in search of an author. In fact, based on the father's idea which "one can be thrust into life in many ways, in many forms: as a tree or stone, as a water or butterflyor as a woman. It might even be as a character in a play" $(1979, \mathrm{p} .13)$, the author is the person who can give life to his characters through writing them on the script. But here, the author is absent; he has just created his characters in his mind and has abandoned them. Consequently, searching for the author implies the characters' searching for life, and identity. In fact, the author implies the wise old man figure, who is not present in the story and cannot help the characters to achieve and find their lives and identities. The characters are searching for someone who can give life to 
them or who can lead them to their real natures and identities. Therefore, they cannot reach their selves and identities, since they cannot find the author as their leader.

Another person in this drama is the producer, who can be considered as the wise old man. Here, in this drama, as one can see the producer acts like the director and guides the actors to play their roles. As the producer claims, "even nowadays the new writers only give us dull plays to act and puppets to present instead of men, I'd have you know that it is our boast that we have given life, here on this stage, to immortal works" $(1979, \mathrm{p} .12)$, his job is to give life to imaginary characters, while in this drama he is not able to do it. When the father and other characters declare that they are characters from an unwritten script, he and other actors start laughing and do not take them serious. Actually, the producer thinks that "the characters are just in the scripts" $(1979, \mathrm{p} .37)$ and stories and cannot be out of it or as alive being; for this reason, he asks them to get out of that place and calls them as "idiots" $(1979$, p.12) and "amateur actors" (1979, p.32), who are wasting his time. Moreover, when the father asks him to let them be played on the stage he claims that "we present comedies and tragedies here [...]. Where is the script?" (1979, p.15) This aspect represents that the producer is not able to help the characters to be represented on the stage. However, the father tries to convince the producer to take the role of writer as to help them to play on the stage, but the producer refuses to do it and states that "he has never written anything!"(1979, p.32) But finally, the producer tempts to do it "just for fun" (1979, p.33). While in the second act, the producer asks the father and his family to come on the stage and act their drama, he wants the other actors to look at them seriously in order to play their drama individually. This part shows that still the producer cannot believe the characters. However, the producer asks the leading actor and leading actress to play the scene of the father and stepdaughter's relationship. In this regard, the father and the stepdaughter become angry and sad, since the actors do not play professionally and cannot convey the true conversation and gestures; moreover, the stepdaughter gets angry when she sees the leading actress "is not dressed in black" $(1979$, p.50) and thinks that this will not show her identity, since the leading actress comes to her mask and tries to imitate her. Besides that, the mother cannot watch this scene; because it reminds her of their incestuous relationship. Therefore, she cries and suffers, and wants the producer to stop the action.

In addition to all parts, the producer follows the scenes, up to where they reach the last scene, where the story seems to be finished. In this regard, the stepdaughter tries to convince the son to help the last part for the actors. She leads the little daughter to the fountain and does not pay attention to the little boy's gun, while the mother is not satisfied with this scene to happen. But, the producer curiously follows the scenes and does not pay attention to the mother. Finally, the little girl is drowned and the little boy committed suicide, regardless of the other's agonies.

\section{Conclusion}

As a result, in Six Characters in Search of an Author, all the characters cannot achieve their selves, since the producer as the wise old man was not able to give life and identity to them. One can consider that the producer as a wise old man is not able to help the characters with their identities; and whatever he causes to happen makes them sad. In this regard, the wise old man did not help the characters to achieve their selves and true identity. Additionally an author is less important than the rest of characters because of his/her absence. An author, thus, is not the source of creativity, originality or inspiration as expected from authors. So he/she is more passive to take the role of wise old man make the characters capable of being reality, life and identity. Moreover, one can see that the father and the mother were not able to communicate with each other; this shows that they are not able to make a relationship with their anima and animus, which are another ways to achieve their selves and identities.

\section{References}

Guerin, Wilfred L., Earl G. Labor, Lee Morgan, and John R .Willingham. (1960). A HandBook of Critical Approaches to Literature. New York: Harper and Row.

Jung, C.G. (1968). Man and His Symbols. New York: Dell Laurel.

Jung, C.G. (1963). Memories, Dreams, Reflections. New York: Vintage Books.

Jung, C.G. (1958). Psyche and Symbol. New York: Doubleday.

Jung, C.G. (1969). The Archetypes and the Collective Unconscious. New York: Princeton University Press.

Moreno, Antonio. (1970). Jung, God \& Modern Man. Indiana: University of Notre Dame.

Pirandello, Luigi. (1979). Six Characters in Search of an Author, Methuen Drama.

Ragusa, Olga (1980). Luigi Pirandello: An Approach to his Theatre. Edinburgh: Edinburgh University Press.

Snowden, Ruth (2006). Teach Yourself Jung. London: Hodder Education.

Walker, F. (2002). Steven. Jung and the Jungians on Myth: An Introduction. New York: Routledge. 